\title{
Characterization of genital strains of Herpesvirus hominis
}

\author{
ISABEL W. SMITH., J. F. PEUTHERER, AND D. H. H. ROBERTSON \\ Departments of Bacteriology and Venereal Diseases, University of Edinburgh
}

Slavin and Gavett (1946) reported antigenic differences between strains of Herpesvirus hominis (HVH) and subsequent serological studies have allowed strains of HVH to be allocated to one of two types (Pauls and Dowdle, 1967). In addition, an association between the clinical site of infection and the antigenic type of virus recovered has been established (Dowdle, Nahmias, Harwell, and Pauls, 1967; Schneweis, 1967), genital isolates being designated Type 2, while the typical oral, eye, and central nervous system strains are classified as Type 1 . Further studies have shown that these two types of HVH may be distinguished biologically, by the cytopathic effect (CPE) they produce in tissue culture (Munk and Donner, 1963), by the size of pock that develops on the chorioallantoic membrane (Parker and Banatvala, 1967), and by the electron microscopial demonstration of filaments within the nuclei of infected cells (Couch and Nahmias, 1969). Other factors, such as the base composition of the viral nucleic acid and the pathogenenicity in animals, can also be used to differentiate the two types of virus (Nahmias and Dowdle, 1968).

Josey, Nahmias, and Naib (1968) drew attention to a possible link between HVH infection of the cervix and cervical neoplasia. Evidence of the association was obtained in two ways. Firstly, from the results of cytological surveys (Naib, Nahmias, and Josey, 1966), it was apparent that infection of the cervix with HVH was associated with an increased incidence of cellular anaplasia. Secondly, serological studies indicated that sera from women with cervical cancer were more likely to contain antibody to HVH Type 2 than sera from controls matched for age and race (Royston and Aurelian, 1970; Rawls, Tompkins, and Melnick, 1969; Nahmias, Josey, Naib, Luce, and Guest, 1970; Skinner, Thouless, and Jordan, 1971). However, when additional factors such as parity and age at first pregnancy were considered in the selection of control patients, the difference between the two groups became less apparent (Rawls, Adam, and Melnick, 1972). Indeed, in studies of New Zealand (Rawls, Iwamoto, Adam, Melnick, and Green, 1970) and American cancer populations (Smith, Received for publication December 8, 1972
Lowry, Melnick, and Rawls, 1972), no difference could be detected between the carcinoma and control patients.

Further knowledge of the general ecology and particularly the anatomical sites of infection with the two types of $\mathrm{HVH}$ in different populations is obviously relevant to this problem. A previous report (Smith, Peutherer, and MacCallum, 1967) established that in the Edinburgh area a significant proportion ( 49.5 per cent.) of the population in the sexually active range 15 to 25 years does not have detectable antibody to $\mathrm{HVH}$. These individuals are fully susceptible to infection with either type of $\mathrm{HVH}$, and it was therefore considered worthwhile to study the viruses isolated from genital infections. This paper reports observations on the characterization of the viruses isolated from the genital tract of 65 patients.

\section{Material and methods}

\section{CELL CULTURE}

BHK21 cells (MacPherson and Stoker, 1962) and RK cells were propagated and maintained as described previously (Peutherer and Smith, 1966).

\section{VIRUS ISOLATION}

Over the 5-year period ending October 31, 1971, swabs were submitted for virus isolation from patients attending the venereal disease clinic of the Royal Infirmary, Edinburgh, and some private patients referred to the above department by the gynaecologists. The swabs were transferred to the laboratory in Hanks's balanced salt solution containing antibiotics; isolation was attempted in BHK and RK cells and the viruses identified by neutralization with specific antisera.

\section{ANTIGENIC TYPING}

Virus isolates were typed by a modification (Peutherer, 1970) of the microneutralization test (Pauls and Dowdle, 1967), using rabbit antisera to HVH Types 1 and 2. The HF strain was used as the Type 1 reference virus and the MS virus as the Type 2 strain. The neutralizing potency (pN) values for the reference virus strains were calculated for both types of antisera, and the pN differences $\left(\mathrm{pN}_{1}-\right.$ $\mathrm{pN}_{2}$ ) established for each virus isolate allowed these to be allocated to either Type 1 or Type 2 (HF-like or MSlike). 


\section{EGG INOCULATION}

Ten-fold dilutions of each virus isolate were prepared in 1 per cent. skim milk and $0.2 \mathrm{ml}$. inoculated on to the chorioallantoic membrane of 10 to 12-day-old embryonated eggs. The eggs were incubated at $35^{\circ} \mathrm{C}$. for 7 days when the chorioallantoic membranes were excised and fixed in formol saline, and the diameter of at least six discrete pocks was measured with a Vernier hand lens.

\section{ELECTRON MICROSCOPY}

Monolayers of BHK cells were inoculated with sufficient virus to give complete CPE in 24 hours. The cells were harvested using glass beads, fixed in glutaraldehyde, post-fixed in osmium tetroxide, and embedded in araldite (Glauert, 1965). Ultrathin sections were cut on an LKB 1 microtome, stained with uranyl acetate and lead citrate, and viewed in an AEI EM6 electron microscope.

\section{CYTOPATHIC EFFECT}

A low dose of virus was inoculated on to BHK cells. Unstained preparations were examined in the light microscope at daily intervals and the CPE was recorded.

\section{SEROLOGICAL TESTS}

Complement-fixation tests (CFT) and neutralization tests (NT) were performed as described previously (Smith and others, 1967).

\section{SPECIMENS}

During the 5-year period swabs or scrapings were received from 78 female and 91 male patients, all of whom were

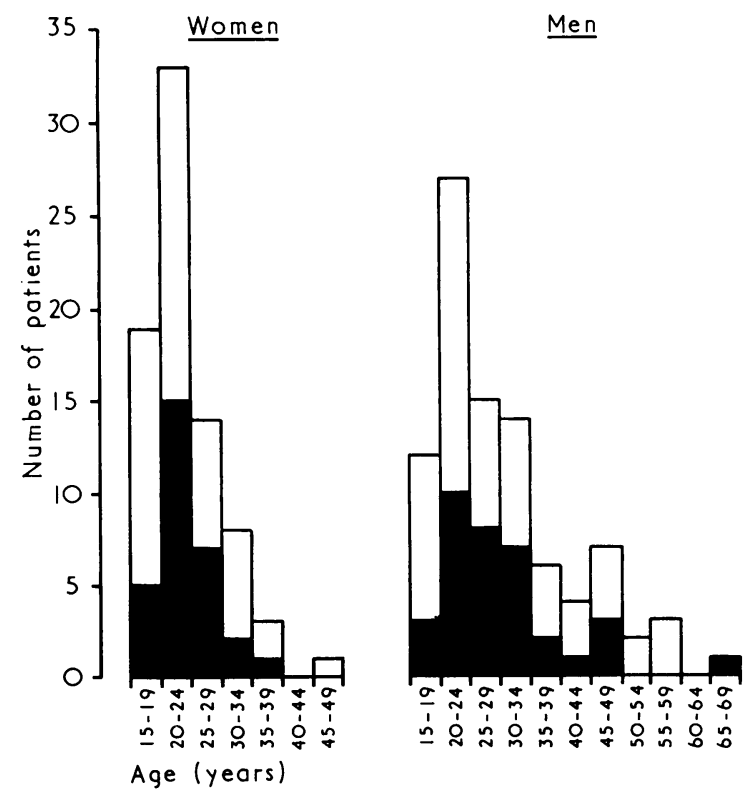

FIG. 1 Age distribution of male and female patients $\square \mathrm{HVH}$ isolated diagnosed as having herpes-like lesions on the external genitalia or the cervix. The age distribution of the patients is shown in Fig. 1. The average age of the female patients was 24 years (15 to 49 ) and that of the male patients 30 years (17 to 68 ). Two-thirds of the female patients were less than 25 years of age while only one-third of the male patients were in this age group.

Specimens from thirty female and 35 male patients yielded $\mathrm{HVH}$ in cell culture, i.e. an isolation rate of 38.5 per cent. in both series. Second isolations were made in eight instances at intervals ranging from 2 days to 4 years. The average ages of the patients from whom $\mathrm{HVH}$ was isolated coincided with those of the total sample, i.e. 24 and 30 years respectively. Cervical scrapings were received from thirteen patients and four of these yielded HVH. From a further four patients specimens were received from both the cervix and the external genitalia. HVH was isolated from both specimens in three cases but from neither specimen in the fourth.

\section{Results}

ANTIGENIC TYPING

Eleven of the virus strains were found to be Type 1 and 54 were Type 2 .

\section{POCK SIZE}

The viruses isolated could be divided into two groups on the basis of the size of pock produced. The average diameter of the pocks of eleven strains was less than $0.75 \mathrm{~mm} .(0.45-0.73)$ while that of the remaining 54 strains was $1.00 \mathrm{~mm}$. or greater $(1.0$ $2 \cdot 5)$.

\section{ELECTRON MICROSCOPY}

Ultrathin sections of cells infected with 64 of the isolates were examined (one strain became contaminated with fungus). In all cases virus particles were observed in both the nucleus and the cytoplasm, but additional structures were found in the nuclei of cells infected with 52 of the strains. These structures have been described as filaments or microtubules and appear either in palisade formation or as 'chainmail' (Fig. 2). These structures were never observed with any of the remaining twelve strains.

\section{CYTOPATHIC EFFECT}

The virus strains could again be divided into two groups on the basis of the CPE produced in BHK cells. One group of eleven isolates produced discrete foci of infection in contrast to the loose aggregates of cells which developed with the remaining 54 strains. These differences were found to be a reflection of the CPE in that, while both groups gave rise to round refractile cells, the second group additionally produced long fusiform syncytia (Fig. 3). 

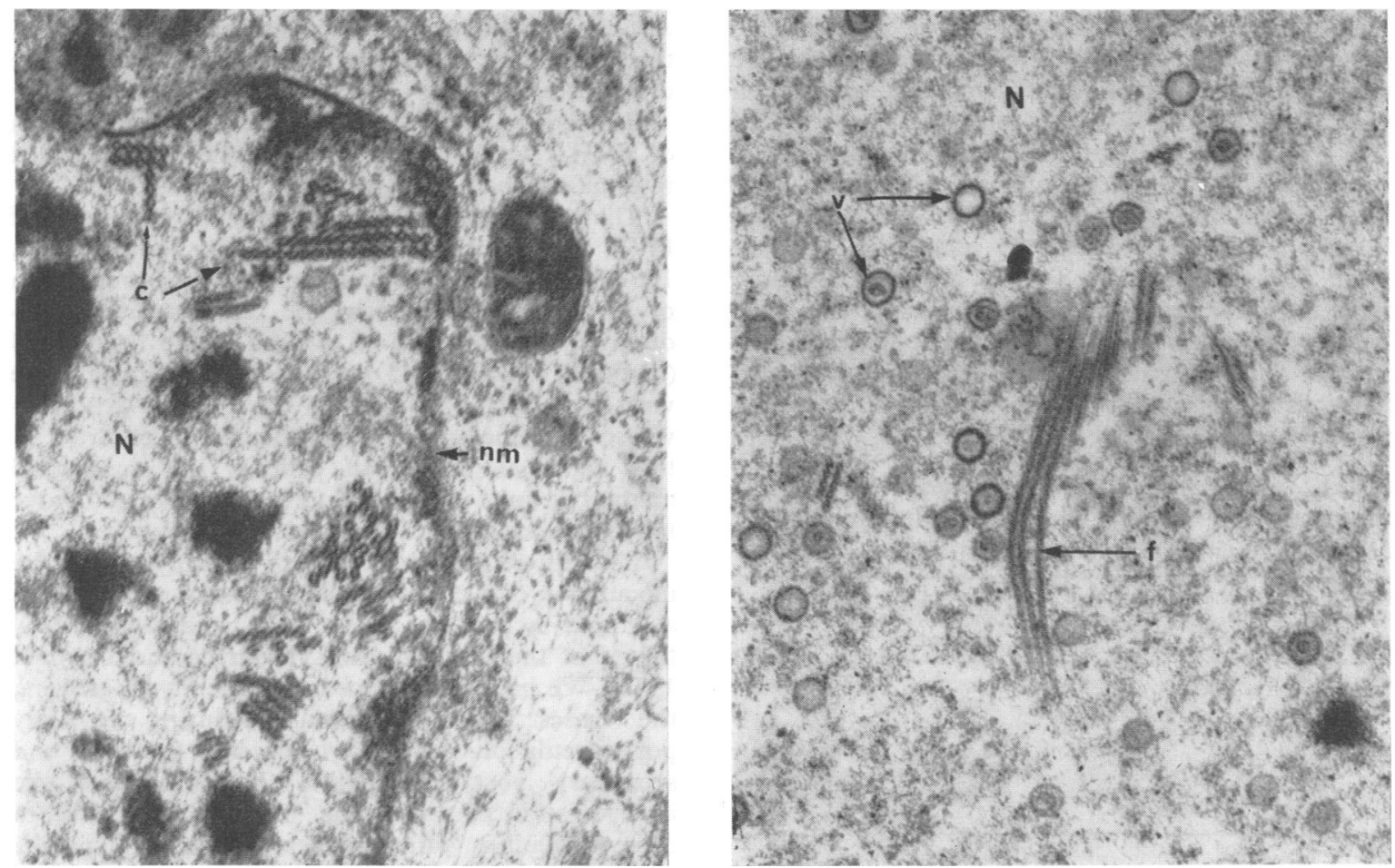

FIG. 2 Electronmicrographs of BHK cells infected with Type $2 \mathrm{HVH}$. N=nucleus; nm=nuclear membrane; $c=$ 'chain-mail' structures; $v=$ virus particles; $f=$ filaments. L.ead citrate, uranyl acetate $(a) \times 60,000(b) \times 40,000$
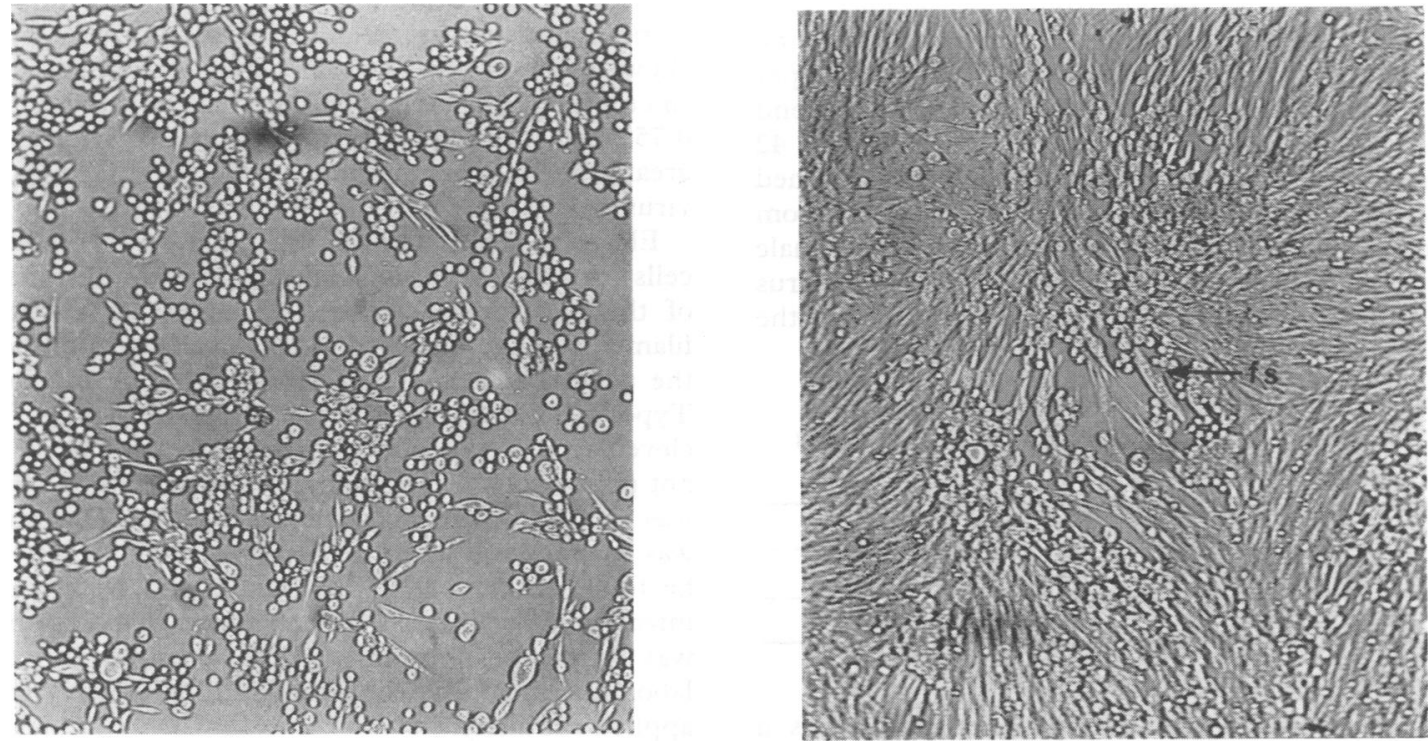

FIG. 3 Unstained light micrographs, showing the cytopathic effect produced by (a) HVH Type 1 and (b) HVH Type 2 in BHK cells. fs=fusiform syncytium. $\times 70$ 
The relationship of these biological attributes to serotype is summarized in Table $\mathrm{I}$, where it can be seen that eleven ( 9 female and 2 male) isolates which were found to be Type 1 serologically produced small pocks on the chorioallantoic membrane, no filaments in the nuclei of infected cells, and a CPE composed of round refractile cells. The remaining 54 strains (21 female and 33 male), which were found serologically to be Type 2 , all produced large pocks on the chorioallantoic membrane and long fusiform syncytia. Electron microscopical examination of infected cells showed that 52 produced filaments and one did not (one strain was lost before examination).

TABLE I Summary of serological and biological properties of 65 strains of Herpesvirus hominis isolated from patients with genital infections

\begin{tabular}{|c|c|c|c|c|}
\hline $\begin{array}{l}\text { No. of } \\
\text { isolates }\end{array}$ & $\begin{array}{l}\text { Antigenic } \\
\text { type }\end{array}$ & $\begin{array}{l}\text { Size of } \\
\text { pock }\end{array}$ & $\begin{array}{l}\text { Presence of } \\
\text { filaments in } \\
\text { nucleus }\end{array}$ & $\begin{array}{l}\text { Cytopathic } \\
\text { effect }\end{array}$ \\
\hline $\begin{array}{r}11 \\
1\end{array}$ & $\begin{array}{l}1 \\
2\end{array}$ & $\begin{array}{l}\text { Small } \\
\text { Large }\end{array}$ & $\begin{array}{l}\text { Absent } \\
\text { Absent }\end{array}$ & $\begin{array}{l}\text { Round cells } \\
\text { Fusiform } \\
\text { syncytia }\end{array}$ \\
\hline 1 & 2 & Large & N.D. & $\begin{array}{l}\text { Fusiform } \\
\text { syncytia }\end{array}$ \\
\hline 52 & 2 & Large & Present & $\begin{array}{l}\text { Fusiform } \\
\text { syncytia }\end{array}$ \\
\hline
\end{tabular}

N.D. $=$ Not done

$\star \quad=$ Small $<0.75 \mathrm{~mm}$.

Large $\geqq 1.0 \mathrm{~mm}$.

SEROLOGICAL STUDIES

First specimens of serum from 159 patients were examined for the presence of complement-fixing antibodies to herpes simplex virus, and 118 (74 per cent.) were found to have such antibodies. Second specimens of serum were only available in 42 instances, but when these paired sera were examined five ( 1 male and 4 female) of the eight patients from whom a Type 1 virus was isolated and eight ( 3 male and 5 female) of the 34 from whom a Type 2 virus was isolated had developed antibody during the course of infection (Table II).

TABLE II Proportion of patients developing antibody during infection with Herpesvirus hominis Type 1 or Type 2

\begin{tabular}{|c|c|c|c|}
\hline \multicolumn{2}{|c|}{ Type 1 virus isolated } & \multicolumn{2}{|c|}{ Type 2 virus isolated } \\
\hline Male & Female & Male & Female \\
\hline $1 / 1$ & $4 / 7$ & $3 / 20$ & $5 / 14$ \\
\hline
\end{tabular}

\section{Discussion}

The age distribution of the patients sampled is a reflection of the population attending venereal disease clinics in that the female patients are younger than the male patients and the peak attendance is in the 20 to 30 -year-old age group. This sample, therefore, does not seem to be unusual in its age distribution.

Before discussing the implications of the isolation of HVH Type 1 from genital sites, the methods used to establish the type of virus will be considered.

The serological differentiation of the two types of HVH has been established (Pauls and Dowdle, 1967), but this distinction depends on the production of suitable antisera. Here the rabbit antisera produced by the injection of the HF (Type 1) and MS (Type 2) viruses could be used to distinguish these viruses and other established Type 1 and 2 herpesviruses (Peutherer, 1970), so the results reported in this paper are valid. In general, this serological method is quite easy to perform, but it might prove too time-consuming for a diagnostic laboratory.

The differentiation of the two serotypes by the inoculation of the chorioallantoic membrane is again a simple technique, but it may be invalidated by failure of the virus to grow (Nahmias and Dowdle, 1968). We have experienced no difficulty in growing the viruses. Death of the embryo during the 7-day post-inoculation period, confluent growth, and secondary pock production can complicate the interpretation of the results. To overcome some of these difficulties, other workers (Nahmias, Dowdle, Naib, Highsmith, Harwell, and Josey, 1968) harvest the membrane 3 days after inoculation and consider that pocks less than $0.5 \mathrm{~mm}$. in diameter are due to Type 1 viruses while those larger than $0.5 \mathrm{~mm}$. are Type 2. The increase in the incubation time to 7 days allowed a clearer distinction of the two types of virus, since the Type 1 serotypes produce pocks less than $0.75 \mathrm{~mm}$. and Type 2 produce pocks of $1.0 \mathrm{~mm}$. or greater. With care, this test can be useful in typing virus isolations.

Electron microscopical examination of infected cells proved a very good method for the distinction of the two types of virus. 52 strains gave rise to filaments in the nuclei of infected cells in addition to the normal virions. These strains all appeared to be Type $2 \mathrm{HVH}$ on the basis of antigenic typing. The eleven strains which were thought to be Type 1 did not produce such filaments, nor did one strain which was thought to be antigenically Type 2 . This strain was examined in more detail but filaments could not be found in cells at $6,12,18,24$, and $48 \mathrm{hrs}$ after infection. It was therefore concluded that this strain was atypical. This test, while possible in some laboratories, is time-consuming and is unlikely to be applied routinely.

Distinguishing the two serotypes of virus by $\mathrm{CPE}$ is rapid, $48 \mathrm{hrs}$ being sufficient in most cases, and observations can be made on unstained preparations 
in the light microscope. Provided the inoculum is not so great that all the cells show CPE in $24 \mathrm{hrs}$, long fusiform syncytia are produced in BHK cells by Type 2 viruses. These syncytia are not so obvious in RK, VERO, or HEp-2 cells and we could not distinguish the two types of $\mathrm{HVH}$ by the effect on chick embryo cells (Figueroa and Rawls, 1969). The type of CPE can be seen on initial isolation, so that no adaptation to tissue culture is necessary. In some cases, continued passage in tissue culture resulted in the production of large flat syncytia such as those produced by MP strains (Hoggan and Roizman, 1959). The production of these large syncytia is not confined to either type of virus but is found in both Types 1 and 2 . If this variation occurs, it is more difficult to distinguish the two types of CPE, but the majority of strains breed true and have retained their cytopathogenic character through many passages.

The four tests used in this laboratory gave a good correlation in 63 of the 64 strains fully tested. It would appear, therefore, that as the tests applied have previously been shown to be of value in distinguishing the two types of HVH (Nahmias, Naib, and Josey, 1971), the identification of eleven of 65 strains (16.9 per cent.) as Type $1 \mathrm{HVH}$ in this series is a valid observation.

From the results of this study, it appears that the close correlation reported previously between virus serotype and site of infection does not hold in Edinburgh. Eleven of the 65 isolates (16.9 per cent.) were found to be Type 1 in contrast to an earlier American report (Nahmias and others, 1971) of nine out of 265 (3.4 per cent.); Type $1 \mathrm{HVH}$ was also recovered from the mouths of four of the latter, two of whom were aged 3 and 8 years.

Nine of the Type 1 strains of $\mathrm{HVH}$ were isolated from female patients. Only specimens from lesions of the external genitalia were received from seven of these patients, but in the other two instances specimens from the cervix yielded Type 1 virus. Normal precautions were taken during the collection of the cervical specimens, but it is obviously impossible to exclude completely the possibility that the virus was picked up from external lesions. The association of Type 1 infection of the lower genital tract and cervical infection with the same type is worthy of further study.

One explanation of this difference might be in the proportion of people who are 'at risk' in the sexually active age group. In a previous survey (Smith and others, 1967) in Edinburgh, it was found that 27.5 per cent. of the 15 to 39 -year age group had no antibody to HVH. A similar figure (26 per cent.) was found in this series. Thus, a quarter of the people in this study would be fully susceptible to infection with either type of virus. Type 1 virus is widely distributed in the community, and both primary oral and recurrent herpes occur in the young adult age group. Contact with a partner suffering from oral infection or the common herpes labialis or facialis could lead to transfer of the virus to the genitalia by direct oro-genital contact or via contaminated fingers. In one instance, there was circumstantial evidence that a partner of one of the female patients from whom a Type $1 \mathrm{HVH}$ was isolated had suffered from a cold sore shortly before the patient developed genital herpes. This patient had no neutralizing antibodies to HVH at the onset of infection but as she subsequently developed antibody this was considered to be a primary infection.

Paired sera were collected from only 42 patients, but by use of both complement-fixation and neutralization tests it was possible to show that five of the patients from whom a Type 1 virus had been isolated and eight of those from whom a Type 2 virus was isolated developed antibody during the course of infection. It was necessary to employ both tests, since complement-fixing antibody can be detected before neutralizing antibody (unpublished observations) and it was therefore possible to confirm the change in antibody status by the use of this latter test. Thus 13 of these 42 genital infections were primary in nature. These thirteen patients were all between 18 and 25 years of age, except for one 39-year-old male. In Edinburgh, therefore, primary genital herpetic infections can occur with either type of virus.

The early American reports (Royston and Aurelian, 1970; Rawls and others, 1969; Nahmias and others, 1970) were based on predominantly Negroid populations, but the latest survey (Rawls, Gardner, Flanders, Lowry, Kaufman, and Melnick, 1971) investigated populations of different socio-economic groups. It was found that, of the higher socioeconomic group, 40 out of 90 (44 per cent.) of the patients had no antibody to either type of $\mathrm{HVH}$ while 16 out of 85 (18.8 per cent.) of the lower socio-economic group had no antibody. These groups, therefore, contained a reasonable proportion of people who were at risk to infection with either type of virus. Some primary infections are recorded but, of an unspecified number of viruses (more than 30 ), only two were Type 1 . Thus a population with a fair proportion of persons 'at risk' does not necessarily give rise to Type 1 genital infections. The proportion of genital Type 1 infections in Edinburgh may be a reflection of the size of the population 'at risk', as well as of sexual practices and hygiene. The possibility of the oro-genital spread of $\mathrm{HVH}$ infection is worthy of further study. 


\section{Summary}

During a 5-year period Herpesvirus hominis was isolated from the external genitalia or cervix of 65 (30 female and 35 male) patients. The virus isolates were characterized by antigenic typing, pock size, appearance of infected cells in the electron microscope, and cytopathic effect in tissue culture cells. Eleven of these viruses were found to be Type 1 . Reasons for this high incidence of Type 1 infection of the genital tract are discussed.

The authors would like to thank the staff of the Venereal Diseases Department for their co-operation, Mr. E. J. Gowans for the electron microscopy, and Mrs. Ann McGowan for technical assistance. This work was partly supported by a grant from the Cancer Research Campaign.

\section{References}

Couch, E. F., and Nahmias, A. J. (1969) f. Virol., 3, 228

Dowdle, W. R., Nahmias, A. J., HaRWell, R. W., and Pauls, F. P. (1967) F. Immunol., 99, 974

FigueroA, M. E., and RAWLs, W. E. (1969) f. gen. Virol., 4, 259

GLAUERT, A. M. (1965) 'The fixation and embedding of biological specimens', in 'Techniques for Electron Microscopy', ed. D. Kay, 2nd ed., p. 166. Blackwell Scientific Publications, London

Hoggan, M. D., and Roizman, B. (1959) Amer. f. Hyg., 70, 208

Josey, W. E., Nahmias, A. J., and NaIB, Z. M. (1968) Amer. F. Obstet. Gynec., 101, 718

MACPherson, I., and Stoker, M. (1962) Virology, 16, 147

Munk, K., and Donner, D. (1963) Arch. ges. Virusforsch., 13, 529

Nahmias, A. J., and Dowdle, W. R., (1968) Progr. med. Virol., 10, 110

,-- NaIB, Z. M., Highsmith, A., HaRWELl, R. W. and Josey, W. E. (1968) Proc. Soc. exp. Biol. (N.Y.), 127,1022

—, Josey, W. E., NaIB, Z. M., LuCE, C. F., and Guest, B. A. (1970) Amer. F. Epidemiol., 91, 547

- NaIB, Z. M., and JoseY, W. E. (1971) In "From Molecules to Man", ed. M. Pollard, p. 73 (Perspectives in Virology, vol. 7). Academic Press, New York
NaIB, Z. M., Nahmias, A. J., and Josey, W. E.' (1966) Cancer (Philad.), 19, 1026

Parker, J. D. J., and Banatvala, J. E. (1967) Brit. F. vener. Dis., 43, 212

Pauls, F. P., and DowdLe, W. R. (1967) f. Immunol., 98, 941

Peutherer, J. F. (1970) f. med. Microbiol., 3, 267

- and SMith, I. W. (1966) f. Path. Bact., 92, 230

Rawls, W. E., Adam, E., and MrLnick, J. L. (1972) 'Geographical variation in the association of antibodies to herpesvirus type 2 and carcinoma of the cervix', in 'Oncogenesis and Herpesviruses', Proc. Symp. Cambridge, 1971, ed. P. M. Biggs, G. de-Thé, and L. N. Payne, p. 424. International Agency for Research on Cancer, Lyon.

- Gardner, H. L., Flanders, R. W., Lowry, S. P., Kaufman, R. H., and Melnick, J. L. (1971) Amer. $\mathcal{F}$. Obstet. Gynec., 110, 682

- Iwamoto, K., Adam, E., Melnick, J. L., and GrEEN, G. H. (1970) Lancet, 2, 1142

-, Tompkins, W. A. F., and MelNICK, J. L. (1969) Amer. F. Epidemiol., 89, 547

Royston, I., and AURELIAN, L. (1970) Ibid., 91, 531

SCHNEWEIS, K. E. (1967) Dtsch. med. Wschr., 92, 2313

SkinNer, G. R. B., Thouless, M. E., and JoRdAN, J. A. (1971) f. Obstet. Gynaec. Brit. Cwlth., 78, 1031

Slavin, H. B., and Gavett, E. (1946) Proc. Soc. exp. Biol. (N.Y.), 63, 345

Smith, I. W., Peutherer, J. F., and MacCallum, F. O. (1967) f. Hyg. (Camb.), 65, 395

Smith, J. W., Lowry, S. P., Melnick, J. L., and Rawls, W. E. (1972) Infect. Immunity, 5, 305

\section{Caractérisation des souches génitales d'Herpes} virus hominis

\section{SOMMAIRE}

Pendant une période de cinq ans, le virus de l' Herpes virus hominis (NVS) a été isolé des voies génitales externes et du col de l'utérus chez 65 malades ( 30 femmes et 35 hommes). Les isolements viraux furent caractérisés par le typage antigénique, la dimension des pustules, l'aspect des cellules infectées au microscope électronique et l'effet cytopathique sur les cellules de culture cellulaire. Onze de ces virus furent trouvés de type I et l'on discute de la haute incidence de l'infection de type I dans les voies génitales. 